\title{
A genetikai diabeteskockázat hatása a csontanyagcsere-energia-háztartás kapcsolatokra
}

\author{
Fék Attila $^{1}$ - Buday Barbara dr. ${ }^{2}$ - Kovács Györgyi ${ }^{2}$ - Vitai Márta dr. ${ }^{2}$

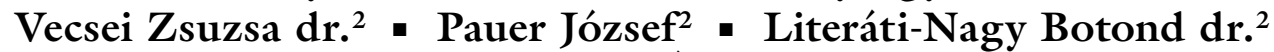 \\ Bezzegh Katalin dr. ${ }^{2}$ - Péterfai Éva dr. ${ }^{2}$ - Korányi László dr. ${ }^{2}$ \\ ${ }^{1}$ Therapiezentrum Wolkersdorf, Schwabach, Németország \\ ${ }^{2}$ DRC Gyógyszervizsgáló Központ Kft., Balatonfüred
}

\begin{abstract}
Bevezetés: A 2-es típusú cukorbetegség fokozott csonttörési kockázattal jár, hiányzik a cukoranyagcsere és a csontátépülés közötti kapcsolat. Nem ismert, hogy ez a romló anyagcserehelyzet miatt alakul ki vagy a diabetes genetikai kockázatának része. Célkitüzés: A szerzők 2-es típusú cukorbetegekben e kapcsolat hiányának hátterét kívánták tisztázni. Módszer: A cukorterhelések és hyperinsulinaemiás-normoglykaemiás klemp alapján 18 egészséges, de a 2-es típusú cukorbetegség genetikai kockázatát hordozó nőt (családban elsőfokú 2-es típusú cukorbeteg rokon) hasonlítottak 26 negatív családi anamnézisű egészséges nőhöz. Eredmények: Az egésztest-cukorfelhasználás és a csont metabolikus egységei közötti kapcsolat a diabetes genetikai kockázatát hordozó nőkben hiányzott, amint a manifeszt cukorbetegekben is. A kockázati csoportban csökkent a nagy molekulájú, kis denzitású és nőtt a kis molekulájú, magas denzitású LDL-molekulák mennyisége, ami gyulladásos citokinszaporulattal és a csontbontás túlsúlyával társult. Következtetések: Az eredmények alapján a kapcsolat hiánya nem a romló inzulinérzékenység és romló anyagcserehelyzet következménye, hanem a genetikai kockázat egyik jellegzetessége. A glükózintolerancia és az inzulinrezisztencia kialakulását megelőző lipideltérés oka nem ismert. Orv. Hetil., 2015, 156(25), 1007-1013.
\end{abstract}

Kulcsszavak: 2-es típusú diabetes mellitus, genetikai kockázat, csontanyagcsere, lipidek

\section{The effect of genetic risk of diabetes on bone and energy homeostasis connections}

Introduction: Type 2 diabetes is associated with increased risk of bone fractures, and the connection between bone remodeling and carbohydrate homeostasis is decoupled. It is not known whether these phenomena are the consequence of the deteriorating glucose metabolism, and the increasing insulin resistance or they belong to the genetic risk of type 2 diabetes. Aim: The aim of the authors was to clarify the impact of genetic risk on bone and carbohydrate homeostasis connections. Method: Hyperinsulinemic-normoglycemic clamps, and oral and iv. glucose loads were done to select 18 metabolically healthy females with first degree type 2 diabetic relatives -and 26 without diabetic relatives. Results: The connections between total body glucose utilization and the activity of the bone metabolic unit were missing in healthy females with the genetic risk of type 2 diabetes, like in those with manifest diabetes. In this risk group the level of low-density-large molecular sized LDL lipids were decreased, while the high-density LDL group with low molecular size was increased. The latter change was in significant connection with increased interleukin-6 levels and increased bone resorption within the bone metabolic unit. Conclusions: These data suggest that the missing connection between glucose and bone metabolism is not the consequence of the developing insulin resistance and deteriorating glucose metabolism, but rather it belongs to the inherited diabetes risk. The etiology of this early alteration, which develops prior to glucose intolerance and insulin resistance is unknown and needs further investigations.

Keywords: type 2 diabetes, genetic risk, bone metabolism, lipids

Fék, A., Buday, B., Kovács, Gy., Vitai, M., Vecsei, Zs., Paner, J., Literáti-Nagy, B., Bezzegh, K., Péterfai, É., Korányi, L. [The effect of genetic risk of diabetes on bone and energy homeostasis connections]. Orv. Hetil., 2015, 156(25), 1007-1013.

(Beérkezett: 2015. április 7.; elfogadva: 2015. április 30.) 


\section{Rövidítések}

$\mathrm{ADA}=$ American Diabetes Association $; \mathrm{BMD}=($ bone minaral density) csontdenzitás; $\mathrm{BMU}=$ (bone metabolic unit) csontanyagcsere-egység; DEXA = kettős röntgensugárabszorpciometria; 2DM = 2-es típusú diabetes mellitus; HOMA-IR = homeostasis model assessment; IR = inzulinrezisztencia; $\mathrm{HNK}=$ hyperinsulinaemiás-normoglykaemiás klemp; $\mathrm{M}-\mathrm{l}=$ egész test cukorfelhasználása $(\mathrm{mg} / \mathrm{kg} / \mathrm{min})$, az inzulinérzékenység jellemzője; $\mathrm{OCN}=$ oszteokalcin; OGTT = orális glükóztolerancia-teszt; OPG = oszteoprotegerin; ROS = reaktívoxigén-species; sRANKL = oszteoprotegerinligand: szolúbilis receptoraktivátor NF- $\mathrm{BB}$ ligand

A XXI. század népegészségügyi kihívása a korai cardiovascularis halálozáshoz vezető és egyre fiatalabb életkorban induló 2-es típusú cukorbetegség (2DM), és a női és férfi lakosságot egyaránt érintő csontvesztés előfordulásának járványszerü szaporodása [1]. A két betegség morbiditásának párhuzamos növekedése ellentmondásokat rejt magában. Mindkettő összefügg a testsúllyal, de míg a 2DM hátterében az óriási mértékben növekvő elhízás és következményes inzulinrezisztencia az egyik oki tényező, addig az osteoporosis esetében a test magasabb zsírtartalma csontvédő hatású, mégis az osteoporosis „járványáról” beszélhetünk.

A cukorbetegség és az érelváltozások kapcsolata jól ismert és egyértelmü: az érelváltozások legfőbb rizikótényezője maga a diabeteses anyagcserezavar. Nem ez a helyzet a csontok állapotával. Míg az l-es típusú diabetes esetében a csontdenzitás, a BMD már gyakran a diagnózis felállításakor alacsonyabb, törési kockázatuk fokozott és a csontvesztés összefügg az anyagcsere beállításával [2], addig a 2-es típusú cukorbetegséggel társuló csontállapotadatok ellentmondóak, ismeretesek a csökkent [3] és a fokozott BMD-ról szólók $[4,5]$.

Előző vizsgálatunk során [6] nők esetében kerestük az induló cukoranyagcsere-zavar idején, az egészségestől a 2DM-betegekig átívelő beteganyagon a csontok denzitása és a szénhidrát-anyagcsere adatai közötti kapcsolatokat. Adataink az inzulinrezisztencia „gold standard” mérőmódszerét, a HNK-t használva szoros kapcsolatot igazoltak a glükózanyagcsere, inzulinérzékenység és a csontok állapota között az egészséges, változókorban lévő nőkben, amely a glükóztolerancia romlásával és az inzulinrezisztencia kialakulásával megbomlik.

Jelen vizsgálatunkban arra kerestünk választ, hogy a csontanyagcsere-energia-háztartás közötti - a 2DM kialakulásával eltűnő - kapcsolat csak a romló cukorfelhasználás és progrediáló inzulinrezisztencia következménye vagy genetikai diszpozíció is áll a hátterében. A kérdést azért találtuk lényegesnek, mert a 2DM korai időszakában (IFG, IGT) életmódbeli és diétás változtatásokkal, esetleg gyógyszeres beavatkozással a cukorbetegség 50\%-ban megelőzhető, visszafordítható vagy a manifesztáció késleltethető [7, 8, 9], így feltételezhető, hogy egy még korábbi időpontban megkezdett beavatkozás eredményesebb.
A glükózfelhasználás, az inzulinérzékenység, a pancreas- $\beta$-sejt-múködés kapcsolatát a csontanyagcsereegység (BMU) múködésével ilyen vonatkozásban még nem kutatták, ezért teljesen egészséges egyéneket vizsgáltunk aszerint csoportosítva, hogy van-e elsőfokú 2DM-rokonuk vagy nincs, és ez mennyiben befolyásolja az energiaháztartás-csontanyagcsere kapcsolatokat.

\section{Betegek és módszerek}

A résztvevők előzetes felvilágosítását, írásos beleegyezésük és az ETT-TUKEB engedély (12988-2/2003-1018EKU) megszerzését követően a vizsgálatban 26 , olyan anyagcsere-egészséges nő vett részt, akinek nem volt elsőfokú 2DM-rokona (GND) és 18 olyan egészséges nő, akinek volt elsőfokú cukorbeteg (GD) rokona. A vizsgálatból kizártuk azokat, akik a csontanyagcserét ismerten befolyásoló gyógyszert szedtek, endokrin betegségük volt vagy mozgáskorlátozottság miatt feltételezhető volt az inaktivitást kísérő csontvesztés.

A per os 75 g glükózterhelés alapján - az ADA-feltételeknek [10] megfelelően - a résztvevők cukoranyagcsere-egészségesek voltak. Ezt igazolta a HNK-módszerrel mért inzulinérzékenység (érzékenység = nyugalomban, éhomi állapotban az egységnyi inzulin hatására felvett, az egész testtömegre vonatkoztatott glükóz mennyisége: M-1) [11] és az iv. glükózterhelés $(0,3 \mathrm{~g} / \mathrm{ttkg})$ eredménye is.

A testösszetétel, a lumbalis csigolyák $\left(\mathrm{L}_{1-4}\right)$ és a femurnyak denzitás (BMD) mérése DEXA (DPX-MD+, GELunar, Amerikai Egyesült Államok) készülékkel történt.

A csontátépülés (reszorpció/formáció) jellemzésére a csontátépülés markereit használtuk. Mértük az N-MID oszteokalcin-, a $\beta$-crosslaps- (1-es típusú kollagén $C$ terminális telopeptid), az össz-PINP- (1-es típusú teljes prokollagén aminoterminális propeptid) szinteket a Roche (Roche Diagnostics, Németország), a katepszin-K (osteoclast ciszteinproteáz), az oszteoprotegerin (osteoclastgátló glikoprotein), az sRANKL oszteoprotegerinligand (szolúbilis receptoraktivátor $\mathrm{NF}-\kappa \mathrm{B}$ ligand) vérszinteket a Biomedica (Biomedica Medizinprodukt $\mathrm{GmbH}$, Ausztria) diagnosztikai kittek használatával.

A csontformációs és reszorpciós markerekből képeztük a csontbontás/csontépítés viszonyát, a csontanyagcsere-egység aktivitását jelző BMU-indexet (BMUindex $=\beta$-crosslaps $\times$ katepszin $-\mathrm{K} \times$ sRANKL $/ \mathrm{OPG} \times$ PlNP). Bár az OCN a csontban a legnagyobb mennyiségben előforduló nem kollagén típusú fehérje, és a mindennapos orvosi gyakorlatban az osteoblastból származó csontépítés markereként tartjuk számon, meggyőző adat utal arra, hogy nem vesz részt a csontképzésben: az $\mathrm{OCN}^{-/-}$génkiütött állatok csontképzése ugyanis fokozott, azaz nem a csontformációban kell keresni az OCN szerepét [12], ezért a BMU-aktivitást jelző képletből kihagytuk.

Az általános klinikai biokémiai paramétereket Cobas Mira laborautomatán (Roche Diagnostics, Németország) 
mértük. A lipidek frakcionálása lineáris poliakrilamid gélen, elektroforézissel (Lipoprint system, Quantimetrix) történt. A leptin-, rezisztin- (BioVendor, Csehország) és adiponektin- (B-Bridge Int., Amerikai Egyesült Államok) szinteket ELISA-kittekkel határoztuk meg.

A két csoport közötti különbséget Student-féle kétmintás t-próba segítségével értékeltük, míg a metabolikus és csontparaméterek közötti kapcsolatot kétváltozós korrelációs analízissel vizsgáltuk. A szignifikanciahatárt $\mathrm{p}<0,05$ alatt adtuk meg.

\section{Eredmények}

$\mathrm{Az}$ antropometrikus adatokat, valamint a biokémiai vizsgálatok és a DEXA-mérés értékeit az 1. és 2. táblázat tartalmazza. Az OGTT alapján mindkét csoportban normális volt a glükóztolerancia és a klemp vizsgálatok alapján az egésztest-inzulinérzékenységet tükröző cukorfelhasználás (M-1). Nem különbözött a csontok denzitása, a hormonok és a csontmarkerek szintje (2. táblázat). Az egyetlen eltérés a lipidparaméterekben volt. A 2DM genetikai rizikót hordozó csoportban szignifi-

1. táblázat $\mid$ Egészséges, de elsőfokú 2DM-rokonnal rendelkező (GD) és egészséges, de a családban elsőfokú 2DM-rokonnal nem rendelkező (GND) önkéntesek antropometriai és biokémiai adatai

\begin{tabular}{|c|c|c|}
\hline & \multicolumn{2}{|c|}{ Egészséges nők } \\
\hline & GND & GD \\
\hline & $\mathrm{n}=26$ & $\mathrm{n}=18$ \\
\hline Életkor & $44 \pm 10$ & $45 \pm 10$ \\
\hline $\operatorname{BMI}\left(\mathrm{kg} / \mathrm{m}^{2}\right)$ & $26,7 \pm 3,8$ & $27,0 \pm 4,8$ \\
\hline Testzsír (\%) & $42 \pm 6$ & $43 \pm 8$ \\
\hline Glükóz éhomi (mmol/1) & $5,0 \pm 0,4$ & $5,1 \pm 1,5$ \\
\hline Inzulin éhomi $(\mathrm{mE} / \mathrm{l})$ & $11,3 \pm 7,1$ & $11,6 \pm 8,1$ \\
\hline HOMA-IR & $2,46 \pm 1,4$ & $2,72 \pm 2,1$ \\
\hline Ml teljes test $(\mathrm{mmol} / \mathrm{kg} / \mathrm{min})$ & $11,7 \pm 4,2$ & $10,9 \pm 4,6$ \\
\hline Triglicerid (mmol/1) & $1,36 \pm 0,7$ & $1,53 \pm 0,9$ \\
\hline Koleszterin $(\mathrm{mmol} / \mathrm{l})$ & $5,24 \pm 2,0$ & $5,43 \pm 1,0$ \\
\hline VLDL $(\mathrm{mmol} / \mathrm{l})$ & $0,96 \pm 0,3$ & $1,52 \pm 0,8^{*}$ \\
\hline LDL-1 ( $\mathrm{mmol} / \mathrm{l})$ & $0,93 \pm 0,4$ & $0,61 \pm 0,4^{*}$ \\
\hline LDL-3 (mmol/l) & $0,05 \pm 0,1$ & $0,21 \pm 0,2$ * * \\
\hline Non-HDL-koleszterin (mmol/l) & $3,67 \pm 0,9$ & $4,08 \pm 1,1$ \\
\hline $\mathrm{HDL}(\mathrm{mmol} / \mathrm{l})$ & $1,57 \pm 0,5$ & $1,35 \pm 0,6$ \\
\hline Non-HDL/HDL & $2,6 \pm 1,0$ & $3,8 \pm 2,4^{*}$ \\
\hline Leptin $(\mathrm{ng} / \mathrm{ml})$ & $21,4 \pm 14$ & $19,4 \pm 8,1$ \\
\hline Adiponektin $(\mathrm{mg} / \mathrm{ml})$ & $5,4 \pm 3,3$ & $6,00 \pm 2,1$ \\
\hline usCRP (mg/dl) & $1,14 \pm 2,4$ & $0,77 \pm 1,4$ \\
\hline IL-6 (ng/ml) & $1,8 \pm 1,9$ & $2,25 \pm 2,7$ \\
\hline $\mathrm{TNF}-\alpha(\mathrm{ng} / \mathrm{ml})$ & $2,6 \pm 3,9$ & $1,85 \pm 0,8$ \\
\hline
\end{tabular}

${ }^{*} \mathrm{p}<0,01,{ }^{*} \mathrm{p}<0,001$
2. táblázat Egészséges, de elsőfokú 2DM-rokonnal rendelkező (GD) és egészséges, de a családban elsőfokú 2DM-rokonnal nem rendelkező (GND) önkéntesek csont- és csontanyagcserével kapcsolatos adatai

\begin{tabular}{ll|l}
\hline & \multicolumn{2}{c}{ Egészséges nók } \\
\cline { 2 - 3 } & $\mathrm{GND}$ & $\mathrm{GD}$ \\
\cline { 2 - 3 } & $\mathrm{n}=26$ & $\mathrm{n}=18$ \\
\hline BMD-L $_{\mathrm{l}-4}\left(\mathrm{~g} / \mathrm{cm}^{2}\right)$ & $1,12 \pm 0,12$ & $1,10 \pm 0,17$ \\
BMD $_{\text {femur }}\left(\mathrm{g} / \mathrm{cm}^{2}\right)$ & $0,98 \pm 0,12$ & $1,02 \pm 0,17$ \\
Katepszin $(\mathrm{pmol} / \mathrm{l})$ & $13,6 \pm 11$ & $13,0 \pm 6,6$ \\
Oszteokalcin $(\mathrm{ng} / \mathrm{ml})$ & $17,9 \pm 7,9$ & $21,0 \pm 7,0$ \\
PlNP & $50,1 \pm 17$ & $45,9 \pm 18$ \\
SRANKL $(\mathrm{pmol} / \mathrm{l})$ & $3,77 \pm 1,7$ & $4,41 \pm 1,2$ \\
Oszteoprotegerin $(\mathrm{pmol} / \mathrm{l})$ & $3,77 \pm 1,7$ & $4,41 \pm 1,2$ \\
$\beta$-crosslaps $(\mathrm{ng} / \mathrm{ml})$ & $0,37 \pm 0,2$ & $0,49 \pm 0,27$ \\
PTH $(\mathrm{pmol} / \mathrm{l})$ & $3,77 \pm 1,7$ & $4,41 \pm 1,2$ \\
TSH $(\mathrm{IU} / \mathrm{l})$ & $1,63 \pm 1,3$ & $1,64 \pm 0,9$ \\
E-2 (pg/ml) & $73 \pm 82$ & $92 \pm 104$ \\
FSH $(\mathrm{E} / \mathrm{l})$ & $36 \pm 38$ & $30 \pm 41$ \\
Tesztoszteron $(\mathrm{ng} / \mathrm{ml})$ & $1,37 \pm 1,5$ & $0,58 \pm 0,3$ \\
BMU-index & $0,44 \pm 0,3$ & $0,66 \pm 0,6$ \\
& & $\mathrm{p}=0,028$ \\
\hline
\end{tabular}

BMU-index $=\beta$-crosslaps $\times$ katepszin $-\mathrm{K} \times \mathrm{sRANKL} / \mathrm{OPG} \times \mathrm{P} \mathrm{INP}$

kánsan magasabb volt a VLDL-szint és a non-HDL/ HDL koleszterin hányados, csökkent a nagy molekulájú „large bouyant” LDL-1-frakció és nőtt a kis molekulájú, magas denzitású LDL-3-frakció koncentrációja. A csontreszorpciós és csontformációs markerekből képzett BMU-index nem különbözött a csoportok között.

Az inzulinérzékenység (Ml-érték) szignifikáns negatív korrelációt mutatott a GND-csoportban az $\mathrm{L}_{1-4}$ gerincen $(-0,4086 ; \mathrm{p}<0,05)$ és a femurnyakon $(-0,3768$; $\mathrm{p}<0,05)$ mért denzitással (3. táblázat). Ez a kapcsolat a

3. táblázat A metabolikus és adipocytokinadatok kapcsolata a gerinc- és femur-BMD-vel

\begin{tabular}{|c|c|c|c|c|}
\hline & \multicolumn{4}{|c|}{ Egészséges nők } \\
\hline & GND & GD & GND & GD \\
\hline & \multicolumn{4}{|c|}{ BMD-korrelációk } \\
\hline & \multicolumn{2}{|c|}{$\mathrm{L}_{1-4}$} & \multicolumn{2}{|c|}{ Femur } \\
\hline & $\mathrm{n}=26$ & $\mathrm{n}=18$ & $\mathrm{n}=26$ & $\mathrm{n}=18$ \\
\hline $\begin{array}{l}\text { M-1 } \\
(\mathrm{mg} / \mathrm{kg} / \mathrm{min})\end{array}$ & $-0,4086^{*}$ & ns & $-0,3768^{*}$ & ns \\
\hline LDL-1-frakció & ns & $-0,5074^{*}$ & ns & $-0,6195$ * * \\
\hline LDL-3-frakció & ns & $+0,4795^{*}$ & ns & $+0,5639^{*}$ \\
\hline Leptin & ns & ns & ns & $+0,4992$ * \\
\hline Adiponektin & $-0,3947^{*}$ & ns & $-0,4184^{*}$ & $-0,4729^{*}$ \\
\hline IL-6 & ns & $+0,4765^{*}$ & ns & ns \\
\hline
\end{tabular}

GND = egészséges, de a családban nincs elsőfokú 2DM-rokon. ${ }^{*} \mathrm{p}<0,05,{ }^{*} \mathrm{p}<0,01$ 
2DM genetikai rizikót hordozó egészséges nőkben mindkét régióban hiányzott. A GD-csoportban a csökkenő LDL-1-frakció negatív kapcsolatban volt mind a gerinc-, mind a femur-BMD-adatokkal, és a növekvő LDL-3-frakció pedig pozitív korrelációt mutatott (3. táblázat) mindkét területen mért BMD-vel. A genetikai rizikót hordozó GD-csoportban észlelt lipideltérések a GND-csoportban nem mutattak kapcsolatot a csontdenzitással. A GND-csoportban meglévő adiponektin-gerinc-BMD negatív kapcsolat a GD-csoportban nem volt észlelhető, míg a femur-BMD vonatkozásában ilyen különbség nem volt. A leptin csak a GD-femur-BMD-vel volt pozitív kapcsolatban.

Az IL-6 a GD-csoportban mutatott kapcsolatot a BMI-vel és a test zsírtartalmával, cukor- és inzulinadatokkal, a HOMA-IR-rel, valamint az eltérő lipidparaméterekkel (VLDL, LDL-1) és a nagy molekulájú, kis denzitású és a kis molekulájú, nagy denzitású lipidfrakciók arányával, és mindkét csoportban a leptinszintekkel (4. táblázat).

A BMU- (csontbontás/csontépítés markereinek aránya) értékeket a testméretek és a testzsírtartalom nem befolyásolta, viszont az inzulin a GND-csoportban csontvédő (negatív kapcsolat a bontás/építés aránnyal) és a genetikailag a 2DM-mel terhelt egészségesek között ellenkező hatású (4. táblázat). A BMU a GND-csoportban erôs korrelációban volt az M-1-értékkel, ez a kapcsolat a GD-csoportban hiányzik. A gyulladásmarker

4. táblázat |Az IL-6-vérszint és a BMU-aktivitás kapcsolata

\begin{tabular}{|c|c|c|}
\hline & \multicolumn{2}{|c|}{ Egészséges nők } \\
\hline & GND $n=26$ & GD $n=18$ \\
\hline & \multicolumn{2}{|c|}{ IL-6-korrelációk } \\
\hline BMI $\left(\mathrm{kg} / \mathrm{m}^{2}\right)$ & ns & $+0,5639^{*}$ \\
\hline Testzsír (kg) & ns & $+0,6007 * *$ \\
\hline HOMA-IR & ns & $+0,6170$ * * \\
\hline Éhomi inzulin & ns & $+0,6286^{* *}$ \\
\hline Glükóz-AUC ${ }_{\text {OGTT }}$ & ns & $+0,5935^{* *}$ \\
\hline VLDL/LDL-1 & ns & $+0,7452 * * *$ \\
\hline LDL-3/LDL-1 & & $+0,5982 * *$ \\
\hline \multirow[t]{2}{*}{ Leptin } & $+0,4379^{*}$ & $+0,4683^{*}$ \\
\hline & \multicolumn{2}{|c|}{ BMU-korrelációk } \\
\hline Glükóz-AUC $C_{\text {OGTT }}$ & $-0,4013^{*}$ & ns \\
\hline Éhomi inzulin & $-0,4007^{*}$ & $+0,6776^{* *}$ \\
\hline Inzulin $\mathrm{AUC}_{\mathrm{OGTT}}$ & $-0,4315^{*}$ & $+0,6463^{* *}$ \\
\hline $\mathrm{M}-\mathrm{l}(\mathrm{mg} / \mathrm{kg} / \mathrm{min})$ & $+0,5562$ ** & ns \\
\hline HOMA-IR & $-0,5739$ ** & $+0,6525^{* *}$ \\
\hline UsCRP & ns & $+0,7841 * * *$ \\
\hline
\end{tabular}

BMU-index $=\beta$-crosslaps $\times$ katapszin $-\mathrm{K} \times$ sRANKL $/ \mathrm{OPG} \times \mathrm{PINP}$; $\mathrm{GD}=$ egészséges, de a családban van elsőfokú 2DM-rokon; GND = egészséges, de nincs a családban elsőfokú 2DM-rokon.

${ }^{*} \mathrm{p}<0,05,{ }^{* *} \mathrm{p}<0,01,{ }^{* *} \mathrm{p}<0,001$
usCRP és a BMU-aktivitás kapcsolata a GD-csoportban igen erős (4. táblázat). Elgondolkodtató összefüggéseket észleltünk a szérumbilirubin-szint vonatkozásában. A GND-csoportban szignifikáns volt a bilirubin kapcsolata a BMD- $\mathrm{L}_{1-4}$-gyel $(\mathrm{r}=+0,4534, \mathrm{p}<0,05)$ és a $\mathrm{BMD}_{\text {femur }}$-ral $(\mathrm{r}=+0,4655, \mathrm{p}<0,05)$, míg a GD-csoportban az inzulinérzékenységet jelző $\mathrm{Ml}$-értékkel ( $\mathrm{r}=$ $+0,5007, \mathrm{p}<0,05)$ és a VLDL-szinttel $(\mathrm{r}=-0,5339$, $\mathrm{p}<0,05)$.

\section{Megbeszélés}

A csontozat növekedése, szerkezetének folyamatos megújulása, a fizikai hatásokhoz történő állandó alkalmazkodás energiaigényes folyamat, amely nyilvánvalóvá teszi a csontok és az energia-háztartás közötti kapcsolat létét, amelyet az osteoblastok és adipocyták közös mesenchymalis eredete alapján is sejteni lehetett. A zsírsejtekból származó és az energia-háztartásban meghatározó szerepet játszó adipokinek jelentősége a csontszerkezetmegújulás szabályozásában, valamint az osteoblastokból származó OCN kapcsolata az inzulinelválasztással további alapja annak, hogy a csontok oldaláról az energiaellátás felé „feed-back” kontroll múködik. Így a csont is az endokrin rendszer tagja, és az energia-háztartás rendellenességei a csontok állapotát is befolyásolják.

A régen felnőttkori cukorbetegségnek hívott 2DM - amelynek előfordulása nemcsak járványszerúen növekszik, de egyre korábbi életkorban manifesztálódik örökletes betegség, amely a csontállapot romlásával, fokozott törési kockázattal társul. A 2DM korai manifesztációja azt jelenti, hogy a serdülőkorban vagy fiatal felnőttkorban induló 2DM szövődményei - mint a vascularis szövődmények és a patológiájában közös kapcsolati pontokat [13] mutató csontállomány eltérése is még az aktív életkorban fog problémát jelenteni. Fontos lenne tudni, hogy egy korán elkezdett diabetesprevenció jelent-e előnyt a csontok vonatkozásában. Jelenlegi adataink ugyanis arra nem adnak választ, hogy a csontok diabeteshez társuló eltérése a romló anyagcsere következménye vagy az öröklött genetikai rizikóhoz társul.

A kérdés megközelítésére olyan egészséges, de elsőfokú 2DM-rokonnal rendelkező, azaz a 2DM genetikai rizikót hordozó nők csoportjában vizsgáltuk az energiaháztartás és a csontátépülés kapcsolatát, ahol a romló anyagcsere hatása kizárható volt, glükóztoleranciájuk és az inzulinérzékenység „gold standard” módszerével - a klemp technikával - mért inzulinérzékenységük normális volt. Öket viszonyítottuk a minden vonatkozásban illesztett, egészséges csoporthoz, akiknek nem volt a családjukban elsőfokú 2DM-rokon. A két csoport paraméterei csak a lipidszintekben és a lipidfrakciók eloszlásában különböztek. A GD-csoportban nemcsak a VLDL-szint volt magasabb, de a lipidfrakciók is eltolódtak a magas denzitású, kis molekulájú tartomány irányába. Ez a változás nemcsak a BMU-aktivitás változásával mutatott 
szoros kapcsolatot, hanem a gyulladásos IL-6 citokin- és usCRP-szintekkel is.

Adataink arra utalnak, hogy a 2DM genetikai rizikót megtestesítő eltéréseket a lipidanyagcsere területén kell keresnünk. Ezek az eltérések megelőzik mind az inzulinrezisztencia, mind a glükózintolerancia kialakulását. Amint előzőleg leírtuk [6], a 2DM korai időszakában (IFG-, IGT- és gyógyszeres kezelést még nem igénylő 2DM idején) hiányzik a kapcsolat az energia-háztartás és a csont metabolikus egységei között, akárcsak a jelenleg vizsgált anyagcsere-egészséges időszakban a 2DM genetikai rizikót hordozók között. Mindkét esetben a fenti jelenség a lipideltéréssel mutat kapcsolatot.

A lipidek fontos szerepet játszanak a csontmetabolizmusban és a csontok állapotában. Nemcsak alkotórészei a membránoknak és fontos tényezői a mineralizációnak $[14,15]$, hiszen a porcsejtek mineralizációjában részt vevő mátrixvesiculák gazdagok koleszterinben, hanem az NMR-vizsgálatok szerint a kalcifikált csont is tartalmaz lipideket [16], és a lipoproteinek szállítják a csontokhoz a zsíroldékony D- és K-vitaminokat is.

Az osteoporosis és cardiovascularis betegségek közötti kapcsolat $[17,18,19,20,21]$ jelzi, hogy a lipidek okozta diabeteses érelváltozások érinthetik a csontokat ellátó ereket is, ischaemiát, táplálékhiányt, az oszteogenikus prekurzorsejt-utánpótlás hiányát és így csontvesztést okozva.

Vizsgált anyagcsere-egészséges önkénteseinkben a diabetes érkárosító mechanizmusa kizárható, az életkor- és testadatok szerinti egyeztetés miatt az életkorral gyakoribbá váló érkárosító tényezők szerepe is elhanyagolható. Ugyanez vonatkozik az elhízással (és diabetesszel) társuló, az IR elindítójaként számon tartott gyulladásos folyamatokra is. A testsúlyok hasonlóak voltak, tehát az elhízás gyulladást provokáló hatása valami egyéb faktoron keresztül érvényesül, amit a "genetikai rizikó” befolyásol.

A gyulladás hatása nem egyértelmü a transzgén/génkiütéses állatmodellben, a magas NF- $\kappa \mathrm{B}$-aktivitás magas TNF- $\alpha$ - és IL-6-szérum- és zsírszöveti szintekkel társult, de ugyanakkor megnövekedett az energiafelhasználás és javult az inzulinérzékenység [22]. A magas zsírtartalmú diéta okozta IR kialakulásához sem kellett a gyulladásos reakció, és csak a tartós IR társult a macrophagindukált gyulladáshoz [23]. Ezek az adatok is azt sugallják, hogy modern életünkhöz társuló energiaplusz okozta elhízás gyulladást és diabetest generáló hatásához kellenek még a jelenleg fel nem tárt, T2DM-rizikót jelentő genetikai, epigenetikai, külső és belső környezeti tényezők, azaz az öröklött genetika mellé az intrauterin hatások, a táplálkozás, a fizikai aktivitás és a microbiom.

A microbiom vizsgálata az elmúlt tíz évben felértékelődött. A bélrendszerben élő baktériumok - amelyek száma százszorosa a test összes sejtjének - alapvetően befolyásolják a béllumenben keletkező anyagcseretermék összetételét és mennyiségét, azok felszívódását, a mucosa immunfunkcióját, a bél endokrin sejtjeinek funkcióját, a belek motilitását vagy az anyagcserét, angiogenezist, a mucosabarrier funkcióját szabályozó gének átírását. A bélmikrobiom kapcsolata az elhízással, az inzulinrezisztenciával vagy a diabetes minden formájával nemcsak állatkísérletes adatokon, hanem humán vizsgálatokon alapul. A gazdaszervezetben okozott változások összefüggenek az epesav-metabolizmussal, a gyulladásos folyamatokkal, a bélhormonok és hatásuk modulálásával vagy a bélpermeabilitás változásával $[24,25]$. Feltételezésünk szerint, amely azonban célzott vizsgálatokat igényel, a szérumbilirubin-szint és az inzulinérzékenység, a csontdenzitás és a VLDL-szintek közötti kapcsolat talán egy, a genetikai prediszpozíció által meghatározott mikrobiom jelenlétére utal.

Az a tény, hogy a csontbontás/csontépítés markereinek aránya (BMU-index) és az inzulinadatok kapcsolata eltér aszerint, hogy van vagy nincs 2DM genetikai háttér, arra utal, hogy a csontépítésért és -bontásért felelős metabolikus egységekben (BMU) is megjelenik a genetikai rizikó, amely akár az inzulinérzékenységet vagy az inzulin-jelátvitelt érinti.

Adataink alapján feltételezhetjük tehát, hogy a 2DM genetikai rizikóval terhelt nókben az észlelt lipideltérés gyulladásos reakciót indít el, ennek jele a lipidek szoros kapcsolata a gyulladásos IL-6 citokinnel és a BMU-aktivitás változásával.

A hyperlipidaemia, az oxidált LDL és foszfolipidek kialakulása és az általuk indukált gyulladásos reakciók játszszák az elsődleges szerepet az atherogenesisben [26]. A módosult lipoproteinek a csont ereinek subendothelialis részében - az osteoblastok elsődleges tartózkodási helyén - felszaporodnak, és gyulladásos mikrokörnyezetet alakítanak ki. Vizsgálatok sokasága igazolja, hogy a gyulladás gátolja a csontformáló osteoblastok differentációját és segíti az osteoclastokét [27]. A módosult lipoproteinek miatti ROS-szaporulat direkt gátolja az alkalikus foszfatáz és az I-es típusú kollagén aktivitását, és a csontvelőben a progenitor sejteket az osteoblastképzés helyett az adipogenikus vonal felé irányítja. A bioaktív lipidek nemcsak az osteoclast-differentációt fokozzák, hanem fokozzák a csontreszorpciót azáltal is, hogy stimulálják az IL-6- és a RANKL-képzést a csontvelő-stromális osteoblastokban és T-lymphocytákban is [28]. Azaz feltételezhetjük, hogy a 2DM genetikai rizikót hordozókban a lipideltérések gyulladásos reakciót indítanak el, de továbbra sem ismerjük a lipidváltozás okát.

A zsír és cukor formájában feleslegben fogyasztott extra energiatárolásra kerül, fokozódik a perifériás szövetekben a lipidfelhalmozódás. Sejtszinten ennek az energiametabolizmus-regulációnak a színtere a mitokondrium. Alapvető evidenciák bizonyítják, hogy a mitokondriumdiszfunkció, az izomszövet következményes csökkent oxidatív kapacitása kulcsfontosságú az elhízást és a 2DMet megelőző inzulinrezisztencia kialakulásában [29, 30]. A mitokondriumok számának és múködésének csökkenését már igazolták diabeteses állatok és 2DM-betegek izomszövetében [31].

A mitokondriumok csökkent múködését és az izomsejtek fokozott lipidtartalmát a 2DM-betegek elsőfokú 
rokonaiban is kimutatták. A magasabb plazma-FFAszintek és intramiocelluláris lipidtartalom mellett inzulinrezisztenciát is észleltek, amelyet az izomsejtekben észlelhető és öröklött FFA-anyagcserezavar következményének tartottak [32]. A fentieknek ellentmond, hogy a 2DM-ben kimutatott 30\%-os mitokondriumszám-csökkenés még nem csökkenti az izmok FFA-oxidáló kapacitását, miután a mitokondriumok szubsztrátoxidáló kapacitása messze meghaladja a nyugalmi izomzat energiaigényét [33], és a patkányokban a magas zsírtartalmú diéta okozta FFA-emelkedés, bár IR-t okoz, az izmokban a mitokondrium oxidatív kapacitását még növeli is. Hasonló ellentmondás, hogy az indiaiakban a meglévő IR ellenére a mitokondriumok fokozott FFA-oxidációját észlelték [34].

Az Amerikai Diabetes Társaság (ADA) 2014. évi kongresszusán beszámoltunk [35] arról, hogy az életkor és BMI szerint illesztett GND-GN nők esetében a GDcsoportban alacsonyabb a mitokondriumok száma és a membránpotenciál. Ez egyrészt arra utal, hogy a mitokondriumeltérés elsődleges, és nem a kialakuló anyagcsere-eltérés következménye, másrészt feltételezhetjük, hogy a genetikai rizikóhoz társuló zsíranyagcsere-zavar egyik oka éppen a mitokondriumok szintjén keresendő.

\section{Következtetések}

Az inzulinérzékenység „arany standard”-jával és cukorterhelésekkel igazoltan egészséges, de a 2DM genetikai rizikóját hordozó nők esetében az egésztest-cukorfelhasználás és a csont metabolikus egységek közötti kapcsolat - akárcsak a manifeszt cukorbeteg nók esetében - hiányzik. Azaz a kapcsolat hiánya nem a romló inzulinérzékenység és romló anyagcserehelyzet következménye, hanem a genetikai rizikó egyik jellegzetessége. Ezekben a személyekben megváltozik a nagy molekulájú, kis denzitású és a kis molekulájú, magas denzitású LDL-molekulák (LDL-1/LDL-3) aránya, ami gyulladásos citokinszaporulattal és a csont metabolikus egységeiben a csontbontás túlsúlyával társul. A lipideltérés oka tisztázatlan. Az eltérő mitokondriumszám és -múködés a multifaktoriális örökletes diabetes rizikótagjaként a patomechanizmus egyik tényezője lehet.

Anyagi támogatás: A munkát az új Széchenyi Terv Gazdaságfejlesztési Operatív Programja, a GOP-1.1.1-112012-0005 támogatta.

Szerzői munkamegosztás: K. L., F. A.: A vizsgálat tervezése. K. L., P. É.: A kézirat szövegezése. B. B., P. J., L.-N. B., B. K., P. É.: A vizsgálatok végzése. K. Gy., V. M., V. Zs.: Labormunka, statisztikai elemzés . A cikk végleges változatát valamennyi szerző elolvasta és jóváhagyta.

Érdekeltségek: A szerzőknek nincsenek érdekeltségeik.

\section{Irodalom}

[1] Fazeli Farsani, F., van der Aa, M. P., van der Vorst, M. M., et al.: Global trends in the incidence and prevalance of type 2 diabetes in children and adolescents: a systematic review and evaluation of methodological approaches. Diabetologia, 2013, 56(7), 14711488.

[2] Tuominen, J. T., Impivaara, O., Puukka, P., et al.: Bone mineral density in patients with type 1 and type 2 diabetes. Diabetes Care, 1999, 22(7), 1196-1200.

[3] Sert, M., Tetiker, T., Kirim, S., et al.: Type 2 diabetes mellitus and osteopenia: is there an association? Acta Diabetol., 2003, 40(2), 105-108.

[4] Van Daele, P. L., Stolk, R. P., Burger, H., et al.: Bone density in non-insulin-dependent diabetes mellitus. The Rotterdam Study. Ann. Intern. Med., 1995, 122(6), 409-414.

[5] De Liefde, I. I., van der Klift, M., de Laet, C. E., et al.: Bone mineral density and fracture risk in type- 2 diabetes mellitus: the Rotterdam Study. Osteoporosis Int., 2005, 16(12), 1713-1720.

[6] Buday, B., Horváth, T., Kulcsár, E., et al.: Relations between bone status and glucose metabolism with progression of insulin resistance. [A progrediáló inzulinrezisztencia hatása a glükózanyagcsere csontállapot kapcsolatokra.] Orv. Hetil., 2007, 148(24), 1127-1133. [Hungarian]

[7] Lindström, J., Louberanta, A., Mannelin, M., et al.: The Finnish Diabetes Prevention Study (DPS): Lifestyle intervention and 3 -year results on diet and physical activity. Diabetes Care, 2003, 26(12), 3230-3236.

[8] Chiasson, J. L., Josse, R. G., Gomis, R., et al.: Acarbose for prevention of type 2 diabetes mellitus: the STOP-NIDDM randomised trial. Lancet, 2002, 359(9323), 2072-2077.

[9] Diabetes Prevention Program Research Group: Reduction in the incidence of type 2 diabetes with lifestyle intervention or metformin. N. Engl. J. Med., 2002, 346(6), 393-403.

[10] Expert Committee on the Diagnosis and Classification of Diabetes Mellitus: Follow-up report on the diagnosis of diabetes mellitus. Diabetes Care, 2003, 26(11), 3160-3167.

[11] DeFronzo, R. A., Abdul-Ghani, M.: Assessment and treatment of cardiovascular risk in prediabetes: impaired glucose tolerance and impaired fasting glucose. Am. J. Cardiol., 2011, 108(3Suppl.), 3B-24B.

[12] Ducy, P., Desbois, C., Boyce, B., et al.: Increased bone formation in osteocalcin deficient mice. Nature, 1996, 382(6590), 448-452.

[13] Sprini, D., Rini, G. B., Di Stefano, L., et al.: Correlation between osteoporosis and cardiovascular disease. Clin. Cases Miner. Bone Metab., 2014, 11(2), 117-119.

[14] Irving, J. T.: Calcification of the organic matrix of enamel. Arch. Oral Biol., 1963, 8, 773-774.

[15] Tintut, ., Demer, L. L.: Effects of bioactive lipids and lipoproteins on bone. Trends Endocrinol. Metab., 2014, 25(2), 53-59

[16] Reid, D. G., Shanahan, C. M., Duer, M. J., et al.: Lipids in biocalcification: contrasts and similarities between intimal and medial vascular calcification and bone by NMR. J. Lipid Res., 2012, 53(8), 1569-1575.

[17] Hmamouchi, I., Allali, F., Khazzani, H., et al.: Low bone min eral density is related to atherosclerosis in postmenopausal Moroccan women. BMC Public Health, 2009, 9, 388.

[18] Szulc, P., Kiel, D. P., Delmas, P. D., et al.: Calcifications in the abdominal aorta predict fractures in men: MINOS study. J. Bone Miner. Res., 2008, 23(1), 95-102.

[19] Bagger, Y. Z., Rasmussen, H. B., Alexandersen, P., et al.: Links between cardiovascular disease and osteoporosis in postmenopausal women: serum lipids or atherosclerosis per se? Osteoporosis Int., 2007, 18(4), 505-512.

[20] Sinnott, B., Syed, I., Sevrukov, A., et al.: Coronary calcification and osteoporosis in men and postmenopausal women are independent processes associated with aging. Calcif. Tissue Int., 2006, 78(4), 195-202. 
[21] Kiss, J., Buday, B., Literáti Nagy, B., et al.: The relationship of coronary heart disease and bone from a different point of view: is lumbar vertebral density a positive predictor of coronary heart disease in women? [A koszorúér-betegség és a csontállapot kapcsolata másképp: a lumbális csigolyadenzitás a koszorúér-betegség pozitív prediktora nőkben?] Lege Artis Medicinae KID, 2011, 1(3), 43-47. [Hungarian]

[22] Tang, T., Zhang, J., Yin, J., et al.: Uncoupling of inflammation and insulin resistance by NF-kappa B in transgenic mice through elevated energy expenditure. J. Biol. Chem., 2010, 285(7), 4637-4644.

[23] Lee, Y. S., Li, P., Huh, J. Y., et al.: Inflammation is necessary for long-term but not short-term high-fat diet-induced insulin resistance. Diabetes, 2011, 60(10), 2474-2483.

[24] Lankelma, J. M., Nieuwdorp, M., de Vos, W. M., et al.: The gut microbiota in internal medicine: implications for health and disease. Neth. J. Med., 2015, 73(2), 61-68.

[25] Sun, J., Chang, E. B.: Exploring gut microbes in human health and disease: Pushing the envelope. Genes Dis., 2014, I(2), 132139.

[26] Staiger, H., Staiger, K., Stefan, N., et al.: Palmitate-induced interleukin-6 expression in human coronary artery endothelial cells. Diabetes, 2004, 53(12), 3209-3216

[27] Jakab, L.: Bone tissue: rebuilding and inflammation. [Csontszövet: Újdonképződés és inflammatio.] Orv. Hetil., 2014, 155(40), 1575-1583. [Hungarian]

[28] Graham, L. S., Tintut, Y., Parbami, F., et al.: Bone density and hyperlipidemia: the T-lymphocyte connection. J. Bone Miner. Res., 2010, 25(11), 2460-2469.
[29] Hirabara, S. M., Curi, R., Maechler, P.: Saturated fatty acid-in duced insulin resistance is associated with mitochondrial dysfunction in skeletal muscle cells. J. Cell. Physiol., 2010, 222(1), 187-194.

[30] Corpeleijn, E., Hessvik, N. P., Bakke, S. S., et al.: Oxidation of intramyocellular lipids is dependent on mitochondrial function and the availability of extracellular fatty acids. Am. J. Physiol. Endocrinol. Metab., 2010, 299(1), E14-E22.

[31] Van de Weijer, T., Sparks, L. M., Phielixm, E., et al.: Relationships between mitochondrial function and metabolic flexibility in type 2 diabetes mellitus. PLoS ONE, 2013, 8(2), e51648.

[32] Schrawwen, P.: High-fat diet, muscular lipotoxicity and insulin resistance. Proc. Nutr. Soc., 2007, 66(1), 33-41.

[33] Holloszy, J. O.: "Deficiency" of mitochondria in muscle does not cause insulin resistance. Diabetes, 2013, 62(4), 1036-1040.

[34] Nair, K. S., Bigelow, M. L., Asmann, Y. W., et al.: Asian Indians have enhanced skeletal muscle mitochondrial capacity to produce ATP in association with severe insulin resistance. Diabetes, 2008, 57(5), 1166-1175.

[35] Literáti-Nagy, B., Buday, B., Vitai, M., et al.: Gender specific alterations of mitochondrial function in healthy first-degree relatives of type 2 diabetic patients. Diabetes, 2014, 63(Suppl. 1), A364, 1396-P.

(Korányi László dr., Balatonfüred, Ady E. u. 12., 8230 e-mail: laszlo.koranyi@drc.hu)

\title{
MEGHÍl ó
}

\section{A Szent Margit Kórház Intézeti Tudományos és Kutatás Etikai Bizottsága tisztelettel meghívja az érdeklődőket a következő tudományos ülésére.}

\author{
Időpont: 2015. június 25. (csütörtök) 14.30 óra
}

A rendezvény helyszíne: Szent Margit Kórház - Budapest III., Bécsi út 132. „A" épület, I. emelet, Konferenciaterem

\section{Üléselnök: Prof. Dr. Berényi Marianne}

\section{Előadások}

Dr. Guttman Tamás: A lumbális gerinccsatorna-szükület tünetei és kezelése 20 perc

Dr. Telek Tamás: A gestatiós diabetes aktuális kérdései

\section{Minden érdeklődőt szeretettel várunk!}

